\title{
Геоинформационное картографирование ареалов жизнедеятельности коренных малочисленных народов в природных ландшафтах Дальневосточного федерального округа
}

Наш мир быстро развивается, на окружающую человека природную среду оказывают влияние миллионы фракторов, связанных с человеческой деятельностью. Культура человека фрормирует наглядно облик антропогенного ландшафта, а природное наследие становится ценным лишь с антропоцентрических позиций. Деятельность людей сейчас во все в большей степени "стирает" уникальность мировых экосистем, что является основанием для обозначения особого универсального антропогенного ландшафта. Социум существует во многих форматах, но перестает выступать в главном - быть особым миром гармоничного приспособления человека к природе. Теряется сам смысл хранения высокоэффрективных адаптационных способов биологического выживания человека.

Глобализация поставила в острой форме проблему измерения рисков человеческой деятельности, выраженных через количественную меру как вероятность и реалистичную возможность наступления нежелательных событий и опасностей [26]. Простая формула монополярного мирового порядка перестала действовать к началу третьего тысячелетия, чему подтверждением стали экономико-политическая нестабильность мира и потрясающие его регулярно глобальные кризисы разного происхождения и "окраски" [132, с. 28]. Во всем мире наблюдается кризис жизнедеятельности тех народов, что еще способны обращаться к традиционным знаниям, но не их ценности и приоритеты развития на совпадают с экономическим мейнстримом глобализации [6].

Академик М.Я. Лемешев (1986) определил эколого-экономическую систему как интеграцию экономики и природы, представляющую собой взаимосвязанное и взаимообусловленное фонкционирование общественного производства и протекание естественных процессов в природе [22]. В представлениях философов природа в узком смысле, или естественная (неочеловеченная), представляет собой единство всего косного и живого миров, по сути своей беспредельных в границах своего бытия, где в то же время имеется на разделение существующего на естественное и искусственное, исторически еще более давнее [18]. Географические процессы могут рассматриваться в качестве условия, среды и материальной основы развития человеческого общества, а их движущим условием является не истощительное использование человеком природы, или развитие особого типа многофункционального природопользования [15].

Международной декларацией по окружающей среде и развитию (1992), в частности, 22 -м принципом установлено ${ }^{1}$, что коренное население и его общины, а также другие местные общины призваны играть жизненно важную роль в рациональном использовании и улучшении окружающей среды с уче-

1 Рио-де-Жанейрская декларация по окружающей среде и развитию // Принята Конференцией ОOH по окружающей среде и развитию, Рио-де-Жанейро, 3-14 июня 1992 года. URL: https://www.un.org/ru/documents/decl_conv/declarations/riodecl.shtml

(C) Бочарников В. Н., Егидарев Е. Г., 2021

БОЧАРНИКОВ Владимир Николаевич, д-р биол. наук, профессор, ведущий научный сотрудник Тихоокеанского института географии ДВО РАН (2. Владивосток). E-mail: vbocharnikov@ mail.ru

ЕГИДАРЕВ Евгений Геннадьевич, канд. геогр. наук, ведущий научный сотрудник Тихоокеанского института географии ДВО РАН (2. Владивосток). E-mail: egidarev@yandex.ru 
том их знаний и традиционной практики. Мы не можем безгранично увеличивать использование естественных ресурсов в одном месте, в пределах одной экосистемы или геосистемы нижнего уровня иерархии, теряется естественная фрункциональность природного, и за пределами устойчивости к антропогенному воздействию образуется "экологическая пустыня" [2]. Природный капитал общества, его живые и неживые ресурсы, является ключевым детерминантом благосостояния во всех регионах мира для различных "ячеек" социума.

Принципиальная необходимость сохранения функциональных свойств и естественной природы предопределяется базовым требованием природопользования избегать истощительного использования биологических ресурсов и поддерживать экологическую устойчивость природных ландшафртов [16]. Под природопользованием как особым видом человеческой деятельности понимается любая эксплуатация дикой природы, прямое и косвенное потребительское воздействие человека на экосистемы и ландшафрты, неизбежно вызывающая изменения в состоянии природной среды. Все формы природопользования, от добычи минеральных природных ресурсов и лесозаготовок до ведения рекреационной деятельности, и экологического туризма, формируют и определяют многие виды специфичных нарушений естественной мозаики пространства. В связи с этим идентификация экосистемных услуг, их экономическая оценка из области теоретических научных исследований должны перейти в практическую плоскость и стать выгодными для России, как экологического донора, в смысле әкономической компенсации поддержки экологического равновесия на планете.

Россия, как особенно ее арктические и приравненные к ним северным территории, относится к крупнейшим на планете резерватам дикой природы, с локально существующими поселениями людей в таких крупных регионах как российский Дальний Восток (рuс. 1). В этом крупнейшем регионе страны пространственное мышление остро необходимо для ведения устойчивого неистощительного природопользования, таковое, в свою очередь, должно "сочетать в себе и процедурное мышление, т.н. знание того, как надо действовать, и знание декларативное, т. е. совокупность прошлого опыта о тех или иных событиях и действиях" [12, с. 50]. Ведущим же принципом выявления антропогенных изменений может должно служить раскрытие сущности процессов в динамичном комплексе сообществ людей, растений, животных, микроорганизмов и неживой среды, взаимодействующих как функциональное единство в пределах непрерывной территории или акватории, которая может быть любого масштаба [3].

Гуманитарная география должна изучать процессы и результаты дифференциации геокультурных общностей, тех территориальных общностей людей с устойчивыми стереотипами мышления и поведения, оригинальными системами ценностей и предпочтений, выраженными в специфике социальной и политической культуры, находящими свое отражение в геопространственной (региональной, локальной и т.п.) идентичности [14]. Этнокультурная география изучает процессы и результаты пространственной дифференциации и организации этнокультурных общностей (в частности, компонентов этнической культуры: традиций и норм поведения, образа жизни и бытового уклада, этнических стереотипов и ментальности в целом). Мы вводим в научный оборот понятие "дикая природа" (ДП) как термин, обозначающий целостные, ненарушенные значимым антропогенным воздействием крупные участки естественных природных ландшабртов $[4,5,9]$. Представляется, что в оптике этнокультурного изучения требуется подтверждение того, что у этносов КМНС исторически выражена более тесная, чем у какого-либо иного социального образования зависимость от условий и качества естественных природных геосистем.

Влияние между этнической культурой и природой существует, и влияние это обоюдное: этносы адаптируются к природной среде, фрормируя сложнейшую систему связей с природой - особую в каждом регионе, что и является одним из важнейших фракторов формирования регионального цивилизационного генотипа $[\mathbf{2 4}$, с. 109]. У тверждаем, что в пределах российского Дальнего Востока особое влияние имеет антропогенное преобразование природной среды на среду жизнедеятельности коренных малочисленных народов, а наличие природных ресурсов достаточных для того, чтобы обеспечивать полноценную 


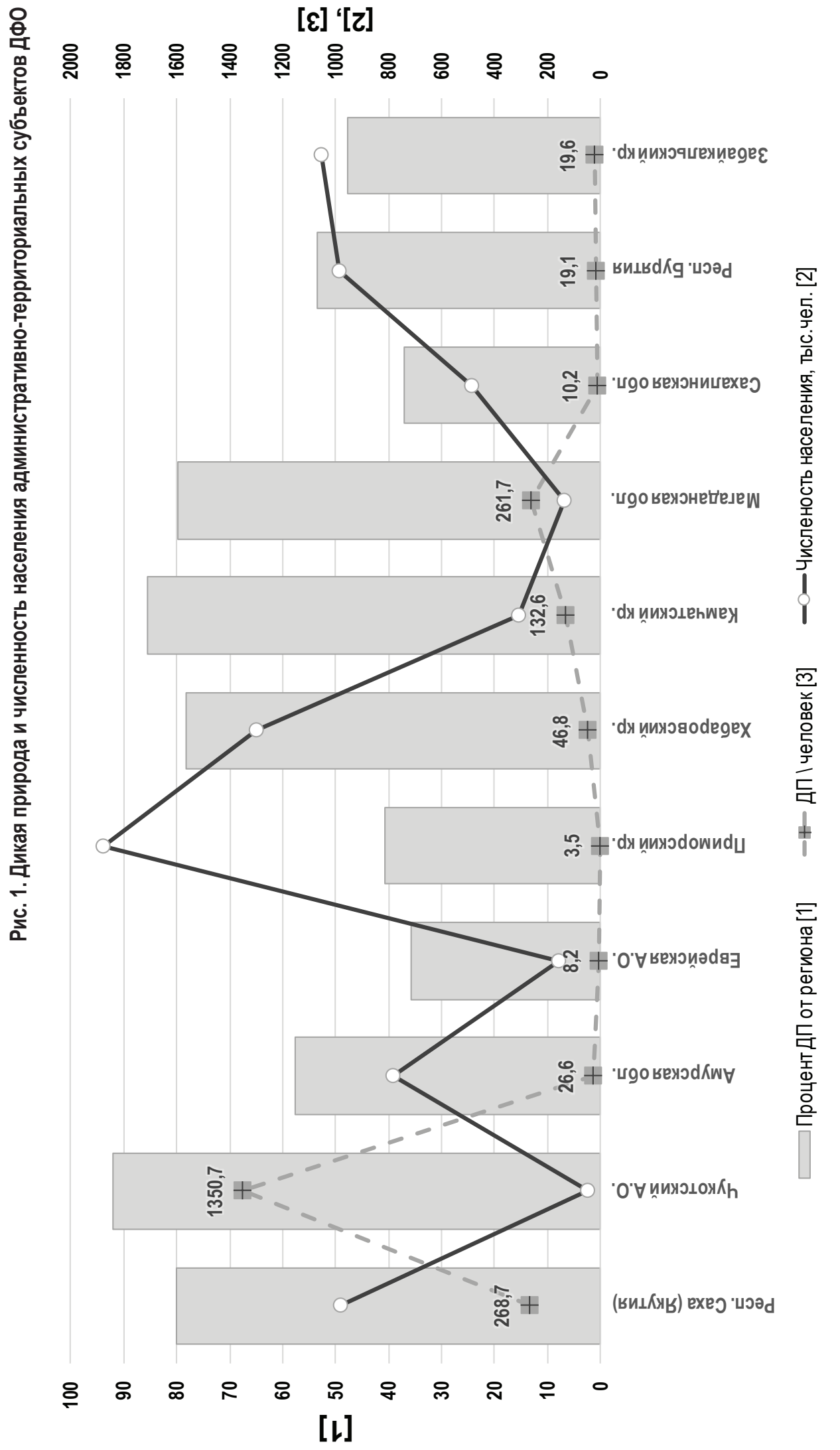


возможность осуществления традиционного хозяйства, промыслы, устойчивое поддержание экологически и экономически безопасной жизнедеятельности, здесь представляет собой критический фрактор жизнедеятельности [1].

\section{Базовая концепция и методология исследований}

Дальневосточный регион исторически представляет собой мультикультурную зону проживания различных этнических групп и народов [20]. Можно уверенно констатировать, что обширная природная территория здесь имеет важное практическое значение в контексте сохранения ценнейшего наследия человечества - территорий проживания и осуществления жизнедеятельности КМНС. К сожалению эта жизнеобеспечивающая зависимость не показывается, и не учитывается должным образом. В современной науке геоиноормационный подход предстает как необходимый инструмент, позволяющий оперативно отображать основные зоны антропогенного воздействия, обозначать локализацию природных и историко-культурных ландшафтов, обеспечивать моделирование и организацию обширных разнородных сведений в единое целое, что позволяет понять ценность изучаемой территории [8].

Этнические ареалы КМНС в современных условиях мы полагаем должны определяться в соответствии с показом мест традиционного природопользования, что приобретает особую значимость при разработке направлений дальневосточной региональной политики (рuc. 2). Такая информация сейчас отсутствует, например, в содержательном смысле можно отметить, что, если этнокультурную маркировку локаций КМHC можно найти в Национальном атласе России, то установить границы их фрактических ареалов жизнедеятельности не представляется возможным по имеющимся в атласе картам [23, c. 226]. Показать это можно только при сопоставлении карт антропогенной нарушенности и этнических ареалов, что и было сделано нами (рuc. 2).

Для картографического отображения численности коренных малочисленных народов Севера (КМНС) нами были взяты сведения двух последних переписей населения, а также подготовлены авторские геоинформационные слои, показывающие этнические ареалы КМНС в пределах ДФО. Первоначально эта работа выполнялась по заказу Учебного центра в 2005 г. для всей России [25]. Далее в 2020 г. было сделано уточнение этнических ареалов и их совмещение с рядом природных характеристик территории ДФО. На основании соотнесения фризико-географических условий территории ДФО, рассматривая также как территориальную особенность природное разнообразие, существующий природный капитал [21] и локации крупных поселений, где проживают этнические представители были выполнены количественные расчеты доли их в общем населении субъектов и показаны этнические ареалы КМНС. Эти результаты приводятся в таблище 1.

По результатам наших расчетов природных и нарушенных ландшафртов России [10] было установлено, что крупнейший по площади ДФО, содержит в пределах своей территории абсолютное большинство сохранившихся крупных участков ДП, суммарной площадью более пяти млн. кв. км $(54,6 \%$ от общей площади в России). Для ДФО в современных его границах отмечается присутствие шести языковых семей и 30 этнических групп [27, с. 634-635]. Установлено, что в трех субъектах РФ в ДФО (Камчатский и Хабаровский края, Чукотский АО), территории, используемые для традиционной деятельности проживания КМНС почти на 100\% совпадают с их историческим размещением [19]. Таким образом, вполне обоснованным является вывод о том, что сохранение дикой природы будет возможно лишь при условии эффективной государственной поддержки традиционного образа жизни КМНС как "хранителей" дикой природы.

Мы полагали также, что географическую информацию следует согласовывать с историей и этнологией. Таким образом, из народов Восточной Сибири были показаны локации эвенков, проживающих в Забайкальском крае и Республики Бурятии. И полностью отображены этнические ареалы народов Дальнего Востока, относящихся к перечню КМНС, и проживающих в пределах территорий Нижнего Амура (Приамурье).

Для Приморья и Сахалина были рассмотрены места проживания и ведения традиционной жизнедеятельности нанайцей, ульчей, негидальцев, орочей, удэгейцев, тазов, айнов, алеутов, эвенков, эвенов, ороков). Как народы 
Таблица 1. Распространение этнических ареалов КМНС в физико-географических областях в пределах ДФО

\begin{tabular}{|c|c|c|c|c|c|}
\hline $\begin{array}{c}\text { Код КМНС } \\
\text { на карте } \\
\text { (Рис. 2) }\end{array}$ & КМHC & $\begin{array}{c}\text { Код } \\
\text { физико- } \\
\text { географической } \\
\text { области на карте } \\
\text { (Рис. 2) } \\
\end{array}$ & $\begin{array}{c}\text { Площадь } \\
\text { (кв. км) }\end{array}$ & $\begin{array}{c}\text { Доля территории } \\
\text { традиционного проживания } \\
\text { и жизнедеятельности КМНС } \\
\text { в границах физико- } \\
\text { географической области } \\
\end{array}$ & \begin{tabular}{|c|} 
Степень \\
сохранности ДП \\
во всей физиико- \\
географической \\
области, в \% \\
\end{tabular} \\
\hline Ал & Алеуты & $б$ & 1378,6 & 98,4 & 53,6 \\
\hline \multirow{3}{*}{ Чк } & \multirow{3}{*}{ Чукчи } & $\sigma$ & 277678,0 & 45,4 & 90,9 \\
\hline & & B & 87263,3 & 14,3 & 94,2 \\
\hline & & г & 243744,3 & 39,8 & 98,7 \\
\hline \multirow{2}{*}{ Чв } & \multirow{2}{*}{ Чуванцы } & B & 6408,9 & 21,4 & 100,0 \\
\hline & & \ulcorner & 23520,5 & 78,6 & 98,1 \\
\hline \multirow{2}{*}{ Эc } & \multirow{2}{*}{ Эскимосы } & б & 5453,4 & 79,7 & 83,5 \\
\hline & & г & 1201,7 & 17,6 & 92,7 \\
\hline \multirow{5}{*}{ Эн } & \multirow{5}{*}{ Эвены } & б & 326,6 & 0,0 & 93,2 \\
\hline & & B & 915795,5 & 65,7 & 88,8 \\
\hline & & г & 322398,0 & 23,1 & 93,9 \\
\hline & & e & 79421,0 & 5,7 & 90,7 \\
\hline & & л & 74560,6 & 5,4 & 78,3 \\
\hline \multirow{2}{*}{ Ит } & \multirow{2}{*}{ Ительмены } & д & 12683,9 & 66,0 & 82,2 \\
\hline & & и & 6536,9 & 34,0 & 94,2 \\
\hline \multirow{4}{*}{$\mathrm{Ha}$} & \multirow{4}{*}{ Нанайцы } & e & 18195,0 & 13,9 & 79,6 \\
\hline & & к & 42712,1 & 32,7 & 82,2 \\
\hline & & л & 32843,0 & 25,2 & 48,7 \\
\hline & & M & 36813,3 & 28,2 & 72,1 \\
\hline \multirow{2}{*}{$\mathrm{He}$} & \multirow{2}{*}{ Негидальцы } & e & 20000,2 & 51,2 & 76,7 \\
\hline & & к & 19056,3 & 48,8 & 77,0 \\
\hline \multirow{3}{*}{ Ни } & \multirow{3}{*}{ Нивхи } & e & 18458,2 & 37,9 & 50,0 \\
\hline & & л & 14218,8 & 29,2 & 60,6 \\
\hline & & M & 15523,3 & 31,9 & 74,5 \\
\hline Op & Орочи & M & 38842,2 & 99,9 & 83,5 \\
\hline $\mathrm{y}_{д}$ & Удэгейцы & M & 56616,9 & 100,0 & 81,5 \\
\hline \multirow{2}{*}{ Ул } & \multirow{2}{*}{ Ульчи } & e & 35556,3 & 80,9 & 66,6 \\
\hline & & M & 8365,1 & 19,0 & 76,0 \\
\hline \multirow{4}{*}{ Юк } & \multirow{4}{*}{ Юкагиры } & б & 1815,7 & 17,7 & 100,0 \\
\hline & & B & 4756,8 & 46,4 & 76,5 \\
\hline & & г & 2656,7 & 25,9 & 92,7 \\
\hline & & л & 1027,1 & 10,0 & 60,0 \\
\hline
\end{tabular}




\begin{tabular}{|c|c|c|c|}
\hline \multirow{7}{*}{$\begin{array}{c}\text { Физико-географические } \\
\text { области за пределами } \\
\text { этнических ареалов } \\
\text { КМНС }\end{array}$} & B & 201164,8 & 90,2 \\
\hline & г & 208689,6 & 91,0 \\
\hline & A & 99022,4 & 91,4 \\
\hline & e & 727520,1 & 81,2 \\
\hline & n & 51723,8 & 94,2 \\
\hline & K & 45805,9 & 77,8 \\
\hline & л & 725799,8 & 84,0 \\
\hline
\end{tabular}

Источник: составлено авторами на основе данных Росстата.

Крайнего Северо-Востока были отображены ареалы долган, юкагиров, нганасаны, эвенки, эвены, чукчи, чуванцы, кереки, коряки, ительмены, камчадалы. К сожалению, из-за отсутствия актуальных сведений по численности и размещению КМНС в наши расчеты (сл. табл. 1) были взяты лишь 13 этносов.

"Дикая природа" - это идея, концепт, система, теория и практика осуществления деятельности по защите естественных фонкций и процессов, окружающей человека среды [4]. Наш расчет сохранности естественных природных функций ландшафртов убеждает, что степень сохранности крупных целостных участков дикой природы для некоторых из них невысока (табл. 2). Менее одного процента составляют мелколиственно-лесные и луговые ландшафрты $(0,9 \%)$, горные тундры и степи $(0,6 \%)$, горные степи и полупустыни $(0,2 \%)$, горные редколесья $(0,4 \%)$. Полностью из них отсутствуют такие ландшафты дикой природы как широколиственно-лесные, горные пустыни, степи и ксерофитные редколесья (0 \%); горные лугостепи и экспозиционные леса $(0 \%)$.

В целом, наиболее высокая степень защищенных ландшафтов дикой природы не достигает четверти от общей площади ландшафта определенного типа в России: к таким относятся ледники $(28,2 \%)$, субнивальные $(22,3 \%)$, хвойные и хвойно-широколиственные горные леса $(21,9 \%)$. Таким образом, нами были сделаны выводы, что из всех 35 ландшафтов, представленных на территории России, находящихся на территории федеральных ООПТ более двух третей (22 ООПТ) представлены в заповедниках и национальных парках минимально (не более 10\% от их наличия). И здесь следует отметить два обстоятельства: первое, как правило, в каждом ландшафте можно вести лишь определённые виды природопользования, и из-за высокой степень ландшафтной трансформации оказывается нередко невозможным ведение традиционные промыслов КМНС.

Второе важное обстоятельство таково: из-за малой степени включенности дикой природы в состав существующих заповедников и национальных парков не обеспечивается должная сохранность биоразнообразия и экосистемных функций. Полагаем также, что биологическое разнообразие и степень сохранности ландшафтов являются зависимыми друг от друга переменными, важно их рассмотрение с позиций понимания традиционного образа жизни и формирования исторических типов устойчивого природопользования на Дальнем Востоке. В природном отношении для будущих исследовательских работ и природоохранной деятельности должны быть выделены следующие приоритетные тенденции (приведены ниже в порядке приоритетности) для поддержания оптимальной степени биоразнообразия.

1) Трансформация наземного, морского и пресноводного биоразнообразия в очагах промышленного загрязнения, обусловленного трансграничным переносом загрязняющих веществ водными и атмосферными потоками, нефртяное, химическое и радиоактивное загрязнения);

2) Снижение уровня, изменение природного состава биоразнообразия и снижение запасов биоресурсов в результате расширения хозяйственной деятельности (нефте- и газодобыча, транспортировка углеводородов, браконьерство, фракторы беспокойства и др.); 
Рис. 2. Физико-географические области и этнические ареалы КМНС ДФО

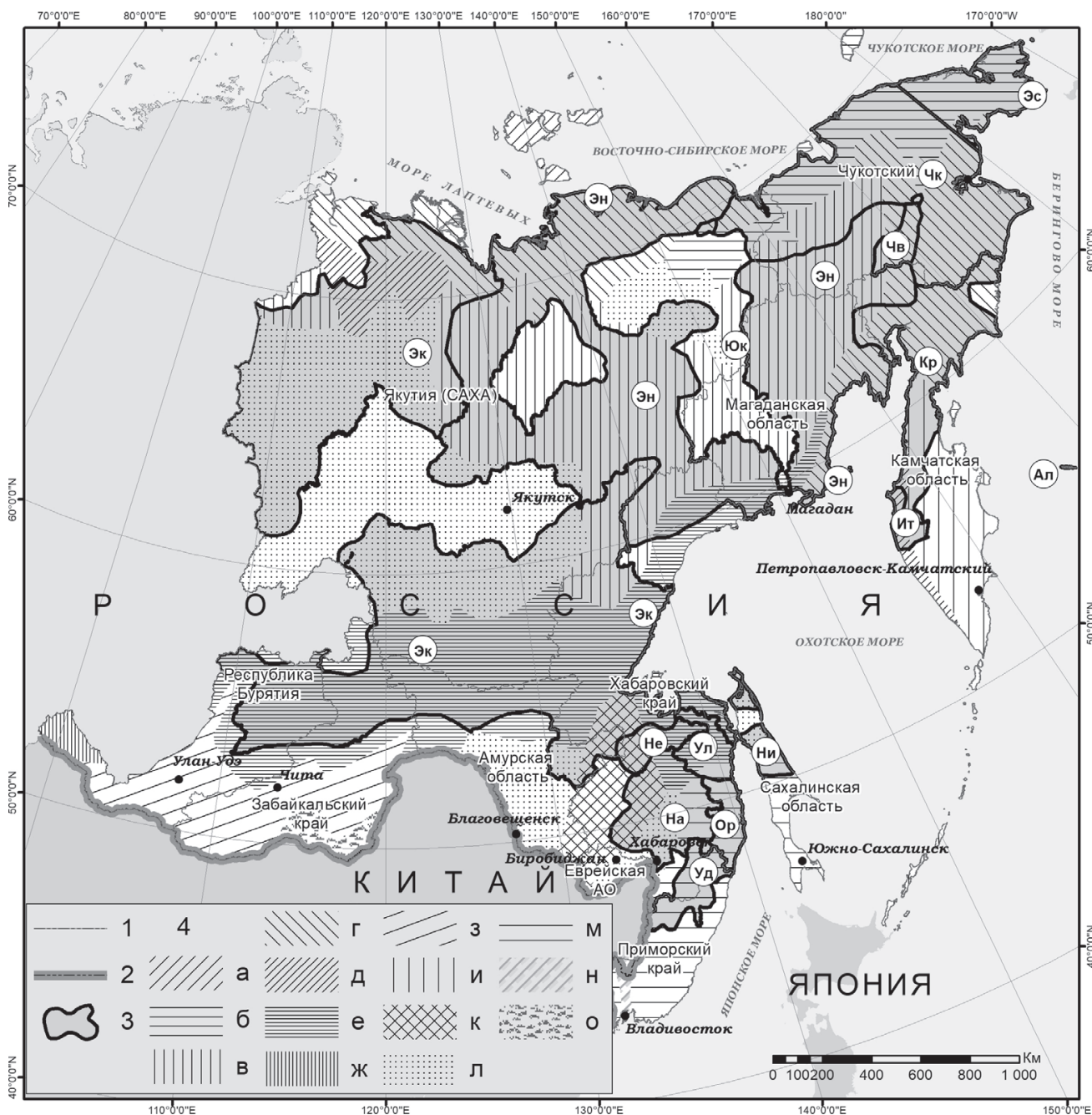

1 - Граница субъектов РФ; 2 - Государственная граница; 3- Территории проживания КМНС; 4 Физико-географические области ДФО: а - Арктические пустыни, б - Арктические тундры, в - Гольцы и редколесья, г - Тундра и лесотундра, д - Лесотундра и редколесья, е - Горные леса и тундра, ж - Альпийские луга и горные леса, з - Гольцы и светлохвойные леса, и - Каменноберезники, к Темнохвойные леса, л - Тайга, м - Кедрово-широколиственные леса, н - Лесостепь, 0 - Степные.

Источник: составлено авторами на основе [23, с. 226].

3) Снижение роли биоразнообразия в обеспечении благосостояния коренных малочисленных народов за счет ухудшения среды их обитания и нарушение условий традиционного природопользования;

4) Трансформация биоразнообразия и местообитаний арктической биоты в условиях меняющегося климата;

5) Сокращение биоразнообразия в результате деградации земель и нарушение условий землепользования [7].

В практическом смысле, следует констатировать, что территория является двухмерной проекцией пространства, и в этом контексте можно принять условие также, что государственная региональная политика является проекцией деятельности государства на отдельные свои территории, которые формально определены как самостоятельные в какой-то степени субъекты 
Таблица 2. Доля официально-охраняемых (в пределах ООПТ) и незащищённых ландшафтов дикой природы в административно-территориальных субъектах ДФО

\begin{tabular}{|c|c|c|c|c|}
\hline $\begin{array}{c}\text { Регион I Тип (код) } \\
\text { ландшафта* }\end{array}$ & $\begin{array}{c}\text { Процент сохранности } \\
\text { ландшафта } \\
\text { (Наличие ДП) } \\
\end{array}$ & $\begin{array}{c}\text { Процент охранности } \\
\text { ландшафта } \\
\text { (Наличие ООПт) }\end{array}$ & $\begin{array}{l}\text { Площадь ДП } \\
\text { (кв. км.) }\end{array}$ & $\begin{array}{l}\text { Площадь ООПт } \\
\text { (кВ. км.) }\end{array}$ \\
\hline Амурская область & 100,00 & 80,20 & 215599,00 & 41639,96 \\
\hline 6 & 0,10 & 15,50 & 124,10 & 104,84 \\
\hline 20 & 8,20 & 22,60 & 17572,20 & 4380,28 \\
\hline 18 & 54,80 & 8,60 & 118309,10 & 13948,63 \\
\hline 35 & & 9,60 & & 325,64 \\
\hline 34 & 34,70 & 14,00 & 76919,90 & 18553,01 \\
\hline 29 & 1,20 & 9,80 & 2673,70 & 4327,56 \\
\hline Республика Бурятия & 100,00 & 21,60 & 191791,00 & 24263,99 \\
\hline 35 & 0,10 & 2,30 & 153,40 & 466,94 \\
\hline 20 & 35,50 & 12,20 & 68037,00 & 10107,24 \\
\hline 18 & 63,70 & 5,90 & 122191,90 & 13441,47 \\
\hline 16 & 0,70 & 1,20 & 1408,70 & 248,33 \\
\hline $\begin{array}{c}\text { Еврейская } \\
\text { Автономная область }\end{array}$ & 100,00 & 59,90 & 13824,40 & 4796,86 \\
\hline 6 & 15,70 & 17,10 & 2173,10 & 912,90 \\
\hline 34 & 7,30 & 17,00 & 1013,20 & 884,44 \\
\hline 29 & 35,70 & 9,80 & 4934,60 & 1620,35 \\
\hline 18 & 41,30 & 15,90 & 5703,50 & 1379,17 \\
\hline Забайкальский край & 100,00 & 153,00 & 213164,70 & 33481,05 \\
\hline 35 & 0,20 & 99,40 & 302,20 & 585,46 \\
\hline 34 & 0,30 & 23,70 & 638,00 & 948,82 \\
\hline 31 & 0,80 & 13,50 & 1811,30 & 4191,76 \\
\hline 20 & 16,30 & 2,00 & 34655,00 & 832,83 \\
\hline 18 & 81,90 & 7,60 & 174611,90 & 24880,73 \\
\hline 16 & 0,50 & 6,90 & 1146,30 & 2041,45 \\
\hline Камчатский край & 100,00 & 196,40 & 413825,80 & 50877,1 \\
\hline 35 & 0,60 & 35,00 & 1178,70 & 454,21 \\
\hline 34 & 0,30 & & 66,90 & \\
\hline 32 & 2,30 & 0,00 & 9674,60 & 4,82 \\
\hline 26 & 9,10 & 10,70 & 38154,10 & 4872,96 \\
\hline 25 & 6,40 & & 26815,20 & \\
\hline 23 & 0,40 & 74,90 & 450,90 & 337,8 \\
\hline 19 & 37,80 & 3,30 & 158441,80 & 5443,41 \\
\hline 18 & 2,30 & 7,00 & 8415,00 & 964,87 \\
\hline
\end{tabular}




\begin{tabular}{|c|c|c|c|c|}
\hline 15 & 13,30 & 3,10 & 55624,80 & 1804,26 \\
\hline 14 & 1,90 & & 7818,90 & \\
\hline 12 & 16,10 & 29,10 & 67250,60 & 22365,70 \\
\hline 22 & 9,50 & 33,30 & 39934,30 & 14629,07 \\
\hline Магаданская область & 100,00 & 58,70 & 384705,30 & 24124,09 \\
\hline 35 & 0,50 & & 96,80 & \\
\hline 34 & 3,60 & 24,10 & 13735,40 & 3920,01 \\
\hline 32 & 2,10 & 6,30 & 8185,90 & 665,63 \\
\hline 19 & 57,40 & 4,20 & 222165,50 & 11455,95 \\
\hline 15 & 5,80 & 14,80 & 22606,30 & 4035,14 \\
\hline 14 & 29,40 & 2,90 & 113672,00 & 3738,14 \\
\hline 25 & 1,20 & 6,40 & 4243,40 & 309,23 \\
\hline Приморский край & 100,00 & 76,30 & 74684,30 & 27720,92 \\
\hline 6 & 6,70 & 17,80 & 5038,00 & 4561,57 \\
\hline 34 & 0,20 & 27,60 & 110,20 & 70,17 \\
\hline 29 & 4,50 & 11,90 & 3370,60 & 4269,78 \\
\hline 18 & 88,60 & 19,00 & 66165,50 & 18819,40 \\
\hline Сахалинская область & 100,00 & 46,80 & 48039,40 & 6823,09 \\
\hline 35 & & 11,60 & & 31,33 \\
\hline 26 & 2,20 & 7,50 & 545,40 & 121,36 \\
\hline 22 & 3,40 & 5,60 & 1091,60 & 70,87 \\
\hline 18 & 34,30 & 6,80 & 16830,80 & 1964,97 \\
\hline 12 & 16,20 & 4,20 & 7982,20 & 477,33 \\
\hline 34 & 43,90 & 10,90 & 21589,40 & 4157,24 \\
\hline Хабаровский край & 100,00 & 198,40 & 624097,20 & 69910,56 \\
\hline 6 & 0,20 & 39,20 & 967,20 & 723,7 \\
\hline 35 & 0,20 & 38,30 & 1059,20 & 999,75 \\
\hline 34 & 13,80 & 8,80 & 86227,50 & 10756,33 \\
\hline 29 & 0,10 & 9,30 & 533,00 & 465,55 \\
\hline 25 & 0,10 & 81,20 & 277,20 & 273,97 \\
\hline 20 & 6,90 & 4,60 & 42839,80 & 2122,11 \\
\hline 19 & 11,60 & 4,30 & 72860,20 & 3269,10 \\
\hline 18 & 64,10 & 10,10 & 400966,90 & 51041,28 \\
\hline 15 & 1,40 & 2,60 & 8538,50 & 257,30 \\
\hline 14 & 1,60 & 0,00 & 9827,70 & 1,47 \\
\hline
\end{tabular}




\begin{tabular}{|c|c|c|c|c|}
\hline $\begin{array}{c}\text { Чукотский } \\
\text { автономный округ }\end{array}$ & 100,00 & 304,20 & 674504,10 & 30985,26 \\
\hline 4 & 0,10 & 98,10 & 421,80 & 435,89 \\
\hline 35 & 0,40 & 9,80 & 1067,40 & 111,14 \\
\hline 34 & 5,30 & 0,00 & 34877,10 & 6,15 \\
\hline 32 & 14,90 & 8,70 & 101418,90 & 9451,31 \\
\hline 3 & 0,20 & 100,00 & 329,30 & 346,18 \\
\hline 2 & 1,40 & 84,70 & 7966,40 & 7290,12 \\
\hline 19 & 66,90 & 2,80 & 456215,40 & 13326,29 \\
\hline 15 & 4,60 & & 30005,70 & \\
\hline 14 & 6,20 & 0,00 & 42202,10 & 18,19 \\
\hline Республика Якутия & 100,00 & 419,40 & 2559194,40 & 795881,74 \\
\hline 4 & 0,30 & 42,70 & 7566,50 & 3460,77 \\
\hline 35 & 0,40 & 41,50 & 7548,30 & 5130,62 \\
\hline 34 & 48,70 & 24,70 & 1250259,40 & 390278,87 \\
\hline 32 & 7,90 & 45,40 & 203311,10 & 94845,41 \\
\hline 25 & 3,80 & 12,40 & 96533,00 & 13013,53 \\
\hline 20 & 1,40 & 22,10 & 36771,20 & 9368,42 \\
\hline 2 & 3,20 & 65,40 & 80041,80 & 55149,12 \\
\hline 19 & 20,50 & 18,30 & 524707,20 & 105447,74 \\
\hline 18 & 5,50 & 23,90 & 140653,00 & 41884,58 \\
\hline 14 & 7,90 & 26,70 & 203202,60 & 68642,01 \\
\hline 1 & 0,40 & 96,40 & 8600,30 & 8660,67 \\
\hline Общий итог & & 1614,90 & 5413429,60 & 1110504,63 \\
\hline
\end{tabular}

*Тип (код) ландшафта: 1 - Арктические (полярные) пустынные; 2 - Арктические тундровые; 3 - Горные арктические(полярные) пустыни; 4 - Горные арктические тундры; 5 - Горные леса (широколиственные и хвойно-широколиственные), 6 - Горные леса (широколиственные), 7 - Горные лесостепи, 8 - Горные луга, 9 - Горные луга (субальпийские), 10 - Горные лугостепи (субальпийские и альпийские); 11 - Горные лугостепи и экспозиционные леса. , 12 - Горные мелколиственные леса и стланики, 13 - Горные пустыни, степи и ксерофитные редколесья, 14 - Горные редколесья, 15 Горные редколесья и стланики, 16 - Горные степи, 17 - Горные степи и пустыни, 18 - Горно-таежные леса, 19 - Горные тундры, 20 - Горные тундры и предтундровые редколесья, 21 - Горные тундры и степи, 22 - Горные тундры и стланики, 23 - Ледники, 24 - Лесостепные, 25 - Лесотундровые, 26 - Мелколиственно-лесные и луговые, 27 - Полупустынные, 28 - Пустынные, 29 - Широколиственнолесные, 30 - Широколиственно-лесные (с лиановыми лесами), 31 - Степные, 32 - Субарктические тундровые. 33 - Субнивальные, 34 - Таежные, 35 - Водные объекты.

Источник: составлено авторами.

[3]. Изменение биоразнообразия, сокращение численности и трансформация местообитаний редких видов - явление последних десятилетий, когда отмечаемое потепление климата и масштабное хозяйственное освоение начали действовать совместно, усиливая негативный эффект. На крайнем Северо-Востоке, особое значение имеют правила регулирования прибрежного рыболовства, поскольку именно лососевые виды как правило составляют суть 


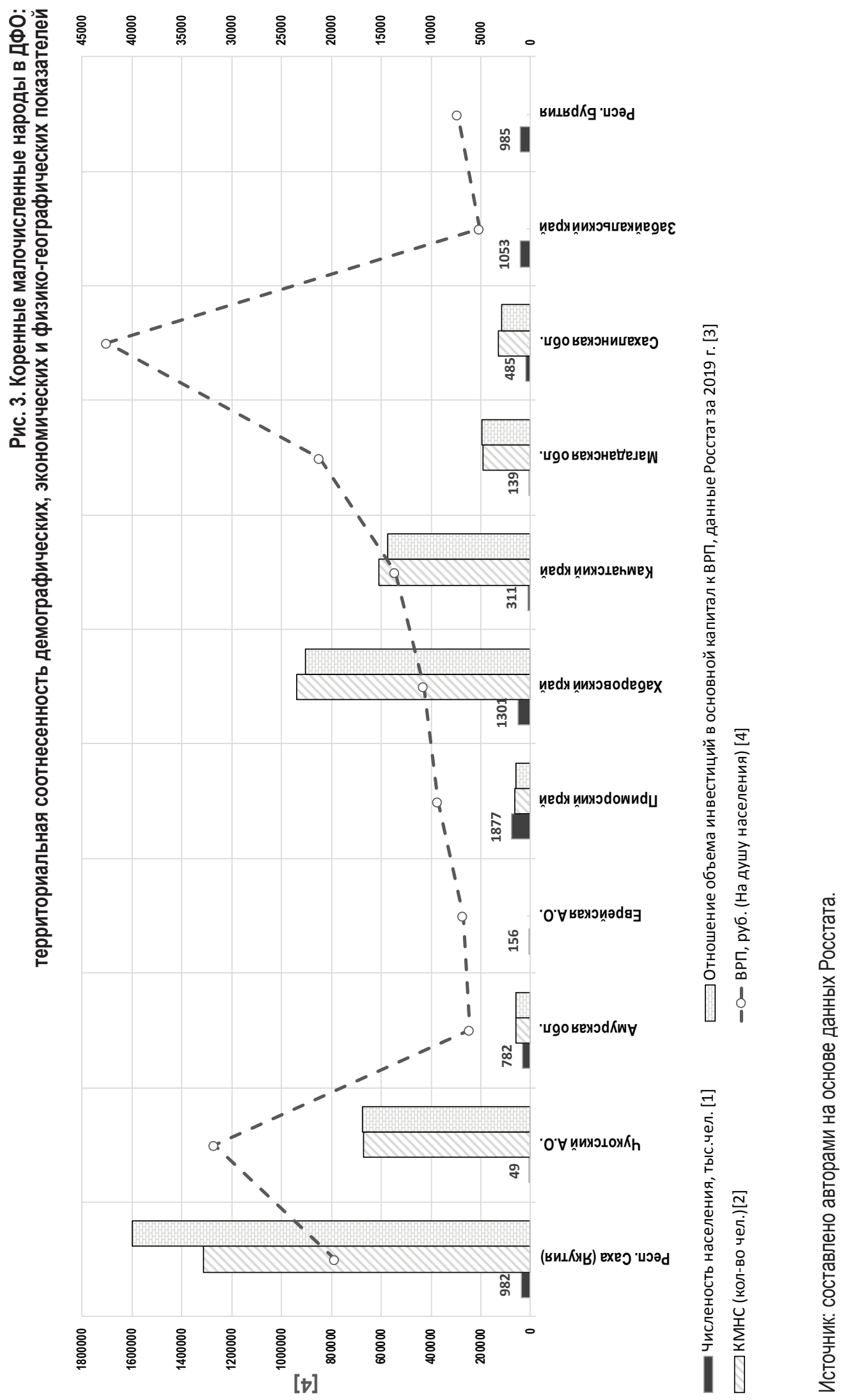


традиционного (аборигенного) природопользования в прибрежно-морской зоне Тихоокеанской России.

Отметим, что повсеместно добыча полезных ископаемых и все фрормы процессов урбанизации коренным образом трансформируют естественную природную среду, при многих формах такого антропогенного воздействия, человеческое общество не способно поддерживать определенный уровень биологического разнообразия, контролируя трансформационные процессы, в своей управленческой деятельности, уменьшая масштабы деградации и потери местообитаний. В социально-экономическом плане, на большей части с ростом уровня бедности среди местного населения и нарастающими проблемами с централизованным "северным завозом" (сезонного снабжения продуктами питания, топливом и товарами первой необходимости) возрастает нагрузка на биоресурсы. Браконьерами тогда невольно выступает в основном местное население, не вовлеченное в современное хозяйство и имеющее крайне низкие доходы.

С другой стороны, не является секретом, что большая часть регионов России испытывает воздействие многих социально-экономических факторов, что позволяет журналистам говорить об "демографоческом опустынивании". Установлено, что 80\% жителей стремятся жить в "прибыльных" городах, так происходит фоктическое сжатие пространства. Пока еще на территории РФ в 28 субъектах РФ компактно проживает 40 малочисленных народов Севера, общей численностью 247,4 тыс. чел (95\% от общей численности КМНС в стране). Удельный вес населения территорий, входящих в перечень мест традиционного проживания КМНС, составлял в среднем по стране по данным переписи 2010 г. 11,3\% от общей численности населения.

Можно отметить, что существующее территориальное неравенство и очаговый характер проживания КМНС нам удалось показать "в первом приближении" на карте как зоны дикой природы. При этом как показывает количественное соотношение нашего пересчета инвестиций к индексу производственной деятельности необходим специальный расчет соответствия дикой природы, экономического развития и жизнедеятельности КМНС. Как первый шаг для подобной постановки задач нами был сделан предварительный расчет (рuc. 3). Полагаем, что необходимо на более детальной основе диффdeренцировать природные гео(эко)системы, или естественными ландшафртами (первой природой), наиболее значимых для КМНС в традиционной жизнедеятельности.

Следующим шагом должна быть более детальная оценка существующих угроз, в т.ч. и международного характера. Здесь также имеет большое значение сопоставлении сведений по официальной сохранности дикой природы, сопряженную с типами охраняемых ландшафтов в переделах, официально существующих ООПТ фредеральной значимости, чтобы было осуществлено нами для всей территории России [9]. Этнические ареалы, диффреренцированные в пределах ландшафтов, которые мы выделили в своей работе, во многом до сих пор совпадают с территориями традиционной жизнедеятельности коренных малочисленных народов, выделяемых ранее, но также они включают фактические места их современного компактного проживания, а также коррелируют своей ценностью с богатыми на природные ресурсы и экосистемные услуги районами.

Достаточно очевидно, что каждый крупный ландшафт, объединенный и приравненный к конкретной физико-географической области, может рассматриваться как уникальная среда обитания КМНC, и в то же время, как как естественный эколого-географический район со специфическим набором-комплексом условий жизни коренного населения и характерного природного окружения. Практически же следует решить вполне понятные вопросы - как и за счет чего обеспечить территориальную, фуннкциональную и ресурсную значимость дикой природы. К примеру, тундры - наиболее обширные северные пространства являются территориями исторически зонами оленеводства, известно о многих проблемах этой деятельности, так же как фракты о том, что в ряде районов наблюдается деградация среды обитаний для таких занятий как оленеводство, не получают никакой государственной оценки, необходимой для решения острых проблем [17]. 
Не следует забывать и о международной ситуации: драйверы глобализации представляют международный финансовый рынок, ТНК, разнообразные сетевые сообщества, обеспечивающие международное взаимодействие, сбыт и перераспределение товаров, продуктов и услуг, информационный и инновационный обмен. Их экспансия может быть отмечена через регистрацию "антропогенной", "очеловеченной", "второй" или "культурного ландшафта" в различной степени составляющих конкретные территория [18]. Рассматривая как высокий уровень проблемности российского государственной политики в отношении сохранения традиционного образа жизни и природопользования КМНC, что отчетливо видно на примере ДФО, следует констатировать, что дальнейшее сокращение дикой природы на территории нашей страны окажет тяжелые экологические последствия как не только на европейскую часть России и Центральную Азию, но окажется значимым для экологического благополучия всей Евразии.

Для российской территории Дальнего Востока особый вызов и смену курса прежней природоохранной политике, инициированной "Западом", осуществлен Китаем, который последнее десятилетие вышел из традиции самообеспечения, настроен решительно действовать и осуществить глобализацию "по-китайски". Китайское руководство выступает за "непрерывное расширение сферы государственных интересов", военное усиление и активную экспансию, путем создания своих активов в том числе и в отношении зарубежных энергоресурсов, стратегических путей сообщения, и собственно территориальных ресурсов [3].

Китайские инвесторы, представленные как государственными структурами, так и частным бизнесом, в своей деятельности одинаково внимательно прислушиваются к политическим решениям руководства страны, и в то же время, вполне успешны во всех своих проектах, являясь желанными партнерами, как в развитых, так и развивающихся странах. $К$ сожалению, до сих пор информации об антропогенном воздействии слишком много, нам представлялось поэтому важным найти и показать простую и понятную основу демонстрации масштабов антропогенной трансформации территории ДФО. Необходимо также и отметить то, что инвестиционный вектор, по сути, означает одобренный государством курс на забвение традиций и аборигенного опыта, потерю самобытной промысловой культуры и опыта непосредственного выживания в суровых условиях тундры, тайги, безлюдного побережья и гор.

Правовым основанием для поддержания существования крупных целостных территорий дикой природы формально является то, что в Российской Федерации принцип защиты и сохранения крупных малонаселенных малоосвоенных районов страны был соотнесен с признанием территорий традиционного обитания (ТТП) и мест традиционной хозяйственной деятельности коренного и местного населения. Данный принцип соответствует п. 1. ст. 9. Конституции РФ: "Земля и другие природные ресурсы используются и охраняются в Российской Федерации как основа жизни и деятельности народов, проживающих на соответствующей территории". В период с 1998 по 2001 гг. в России были приняты три федеральных закона, закрепляющих правовое положение коренных малочисленных народов, но ни один из них не стал "рабочим документом". Полагаем, что нынешний курс на инвестиционную экономику с учетом экономических и внешнеполитических успехов Китая, как значимый для России фрактор диктует нам о необходимости присмотреться к тысячелетнему традиционному опыту бережного освоения аборигенами дальневосточной территории, и не забывать о том, что утрата природного естественного своеобразия природных ландшафтов может быть предотвращена лишь с учетом сохранения традиционного опыта КМHC. 


\section{Литература}

1. Аверин А.Н. Коренные малочисленные народы: динамика развития // Вестник Бурятского государственного унививерситета. 2015. Вып. 14. С. 70-75.

2. Банников А.Г. Основы экологии и охрана окружающей среды. М., 1996. 304 с.

3. Бочарников В.Н. Методологическая интеграция социально-экономической географии, геоэкологии и природопользования в решении проблем сохранения экосистемного разнообразия российского Дальнего Востока // Астраханский вестник экологического образования. 2013. № 4. С. 17-36.

4. Бочарников В.Н. Человекоразмерный концепт "дикая природа" в контексте исследований гуманитарной географии // Социально-экономическая география. Вестник Ассоциации российских географов-обществоведов. 2015. № 4. С. 37-51.

5. Бочарников В.Н. Дикая природа и антропогенный ландшафт: интегрированный опыт геоинформационного картографирования территории России // Географический вестник. 2016. № 2. С. 161-173.

6. Бочарников В.Н. Географическое мышление, культурная география и дикая природа // Известия Российской академии наук. Серия географическая. 2018. № 3. С. $105-116$.

7. Бочарников В. Н. Стратегия биоразнообразия России и региональные приоритеты природопользования в прибрежно-морских регионах Тихоокеанской России // Особо охраняемые природные территории Камчатского края: опыт работы, проблемы управления и перспективы развития: тезисы докладов Второй региональной научно-практической конференции. Петропавловск-Камчатский, Камчатпресс, 2017. 4145.

8. Бочарников В.Н., Блиновская Я.Ю. Геоинформационные системы в природопользовании. Владивосток: МГУ, 2009. 181 с.

9. Бочарников В.Н., Егидарев Е.Г. Новый природоохранный индекс для территории России // Проблемы региональной экологии. 2015. № 5. С. 75-80.

10. Бочарников В.Н., Егидарев Е.Г. Дикая природа в ландшафтах и экорегионах России // География и природные ресурсы. 2017. № 4. С. 38-49.

11. Воскресенский А.Д. Китай в контексте глобального лидерства // Международные процессы. 2004. Т. 2. № 5. С. 21-33.

12. Замятин Д.Н. Гуманитарная география: Пространство и язык географических образов. СПб.: Алетейя, 2003. 331 с.

13. Зевин Л. Мегарегионы в глобаризирующемся хозяйстве // Мировая экономика и международные отношения . 2016. Т. 60. № 8. С. 26-33.

14. Гладкий Ю.Н., Петров А.Н. Гуманитарная география: понятийный статус и самоидентификация // Известия Российской академии наук. Серия географическая. 2008. № 3. C. 15-25.

15. Герасимов И. П. Конструктивная география как наука о целенаправленном преобразовании и управлении природной средой // Известия Российской академии наук. Серия географическая. 1972. № 3. С. 7-11. $328 \mathrm{c}$.

16. Исаченко А.Г. Экологическая география России. СПб. Изд-во СПбГУ. 2001.

17. Клоков К. Б., Хрущев С. А. Оленеводческое хозяйство коренных народов Севера России: инфрормационно-аналитический обзор. СПб. 2004. Т. 1. 182 с.

18. Кобылянский В.А. Философия экологии. Краткий курс. Учебное пособие для вузов. М.: Академический проект, 2010, 632 с.

19. Крюков В.А., Шишацкий Н.Г., Брюханова Е.А., Кобалинский М.В., Матвеев A.M., Токарев А.Н. Потенциал устойчивого развития ареалов проживания и экономическая оценка качества жизни коренных малочисленных народов Севера - Новосибирск: ИЭОПП СО РАН. 2014. 144 с.

20. Кузнецов А. М. Этнополитическая ситуация на Дальнем Востоке России: некоторые проблемы и перспективы // Ойкумена. Регионоведческие исследования. 2012. № 1 (20). С. $67-79$.

21. Кузьминов И. Ф., Нефедова Т. Г. Концентрация производства в агропромышленном и лесопромышленном комплексах и поляризация пространства России // Вестник АРГО. 2012. №. 1. С. 63-75.

22. Лемешев М.Я., Чепурных Н.В., Юрина Н.П. Региональное природопользование: на пути к гармонии. М.: Мысль. 1986. 264 с.

23. Национальный атлас Российской Федерации культурно-ландшафтное районирование территории России. В 4-х т. Т. 4. "История, культура". М.: Роскартография. 2008. 495 c.

24. Рагулина М.В. Коренные этносы сибирской тайги: мотивация и структура природопользования (на примере тофаларов и эвенков Иркутской области). Новосибирск: Изд-во СО РАН. 2000. 163 с.

25. Тураев В.А., Суляндзига Р.В., Суляндзига П.В., Бочарников В.Н. Энциклопедия коренных малочисленных народов Севера, Сибири и Дальнего Востока Российской Федерации. Сер. Библиотека коренных народов Севера. М. 2005. 464 c. 
26. Философия природы сегодня. Ред. И.К. Лисеев, В. Луговской. Пер. с польского языка: В.Л. Васюков, Е.Н. Шульга. М.: "Канон+" РООИ "Реабилитация", 2009. 426 с.

27. Сибирь. Атлас Азиатской России. Новосибирск-Москва: Феория, 2007. 664 с.

28. Global Biodiversity URL: https://www.cbd.int/gbo5 (дата обращения 17.07. 2021).

\section{Транслитерация по ГОСТ 7.79-2000 Система Б}

1. Averin A.N. Korennye malochislennye narody: dinamika razvitiya // Vestnik Buryatskogo gosudarstvennogo univiversiteta. 2015. Vyp. 14. S. 70-75.

2. Bannikov A.G. Osnovy ehkologii i okhrana okruzhayushhej sredy. M., 1996. $304 \mathrm{~s}$.

3. Bocharnikov V.N. Metodologicheskaya integratsiya sotsial'no-ehkonomicheskoj geografii, geoehkologii i prirodopol'zovaniya v reshenii problem sokhraneniya ehkosistemnogo raznoobraziya rossijskogo Dal'nego Vostoka // Astrakhanskij vestnik ehkologicheskogo obrazovaniya. 2013. № 4. S. 17-36.

4. Bocharnikov V.N. CHelovekorazmernyj kontsept "dikaya priroda" v kontekste issledovanij gumanitarnoj geografii // Sotsial'no-ehkonomicheskaya geografiya. Vestnik Assotsiatsii rossijskikh geografov-obshhestvovedov. 2015. № 4. S. 37-51.

5. Bocharnikov V.N. Dikaya priroda i antropogennyj landshaft: integrirovannyj opyt geoinformatsionnogo kartografirovaniya territorii Rossii // Geograficheskij vestnik. 2016. № 2. S. 161-173.

6. Bocharnikov V.N. Geograficheskoe myshlenie, kul'turnaya geografiya i dikaya priroda // Izvestiya Rossijskoj akademii nauk. Seriya geograficheskaya. 2018. № 3. S. 105116.

7. Bocharnikov V. N. Strategiya bioraznoobraziya Rossii i regional'nye prioritety prirodopol'zovaniya $\mathrm{v}$ pribrezhno-morskikh regionakh Tikhookeanskoj Rossii // Osobo okhranyaemye prirodnye territorii Kamchatskogo kraya: opyt raboty, problemy upravleniya i perspektivy razvitiya: tezisy dokladov Vtoroj regional'noj nauchno-prakticheskoj konferentsii. Petropavlovsk-Kamchatskij, Kamchatpress, 2017. 41- 45.

8. Bocharnikov V.N., Blinovskaya YA.YU. Geoinformatsionnye sistemy v prirodopol'zovanii. Vladivostok: MGU, 2009. $181 \mathrm{~s}$.

9. Bocharnikov V.N., Egidarev E.G. Novyj prirodookhrannyj indeks dlya territorii Rossii // Problemy regional'noj ehkologii. 2015. № 5. S. 75-80.

10. Bocharnikov V.N., Egidarev E.G. Dikaya priroda v landshaftakh i ehkoregionakh Rossii // Geografiya i prirodnye resursy. 2017. № 4. S. 38-49.

11. Voskresenskij A.D. Kitaj v kontekste global'nogo liderstva // Mezhdunarodnye protsessy. 2004. T. 2. № 5. S. 21-33.

12. Zamyatin D.N. Gumanitarnaya geografiya: Prostranstvo i yazyk geograficheskikh obrazov. SPb.: Aletejya, 2003. 331 s.

13. Zevin L. Megaregiony v globariziruyushhemsya khozyajstve // Mirovaya ehkonomika i mezhdunarodnye otnosheniya . 2016. T. 60. № 8. S. 26-33.

14. Gladkij YU.N., Petrov A.N. Gumanitarnaya geografiya: ponyatijnyj status i samoidentifikatsiya // Izvestiya Rossijskoj akademii nauk. Seriya geograficheskaya. 2008. № 3. S. 15-25.

15. Gerasimov I. P. Konstruktivnaya geografiya kak nauka o tselenapravlennom preobrazovanii i upravlenii prirodnoj sredoj // Izvestiya Rossijskoj akademii nauk. Seriya geograficheskaya. 1972. № 3. S. 7-11.

16. Isachenko A.G. EHkologicheskaya geografiya Rossii. SPb. Izd-vo SPbGU. 2001. $328 \mathrm{~s}$.

17. Klokov K. B., KHrushhev S. A. Olenevodcheskoe khozyajstvo korennykh narodov Severa Rossii: informatsionno-analiticheskij obzor. SPb. 2004. T. 1. $182 \mathrm{s.}$

18. Kobylyanskij V.A. Filosofiya ehkologii. Kratkij kurs. Uchebnoe posobie dlya vuzov. M.: Akademicheskij proekt, 2010, 632 s.

19. Kryukov V.A., SHishatskij N.G., Bryukhanova E.A., Kobalinskij M.V., Matveev A.M., Tokarev A.N. Potentsial ustojchivogo razvitiya arealov prozhivaniya i ehkonomicheskaya otsenka kachestva zhizni korennykh malochislennykh narodov Severa - Novosibirsk: IEHOPP SO RAN. 2014. $144 \mathrm{~s}$.

20. Kuznetsov A. M. EHtnopoliticheskaya situatsiya na Dal'nem Vostoke Rossii: nekotorye problemy i perspektivy // Ojkumena. Regionovedcheskie issledovaniya. 2012. № 1 (20). S. 67-79.

21. Kuz'minov I. F., Nefedova T. G. Kontsentratsiya proizvodstva v agropromyshlennom i lesopromyshlennom kompleksakh i polyarizatsiya prostranstva Rossii // Vestnik ARGO. 2012. №. 1. S. 63-75.

22. Lemeshev M.YA., CHepurnykh N.V., YUrina N.P. Regional'noe prirodopol'zovanie: na puti k garmonii. M.: Mysl'. 1986. $264 \mathrm{~s}$.

23. Natsional'nyj atlas Rossijskoj Federatsii kul'turno-landshaftnoe rajonirovanie territorii Rossii. V 4-kh t. T. 4. "Istoriya, kul'tura". M.: Roskartografiya. 2008. $495 \mathrm{~s}$. 
24. Ragulina M.V. Korennye ehtnosy sibirskoj tajgi: motivatsiya i struktura prirodopol'zovaniya (na primere tofalarov i ehvenkov Irkutskoj oblasti). Novosibirsk: Izd-vo SO RAN. 2000. 163 s.

25. Turaev V.A., Sulyandziga R.V., Sulyandziga P.V., Bocharnikov V.N. EHntsiklopediya korennykh malochislennykh narodov Severa, Sibiri i Dal'nego Vostoka Rossijskoj Federatsii. Ser. Biblioteka korennykh narodov Severa. M. 2005. 464 s.

26. Filosofiya prirody segodnya. Red. I.K. Liseev, V. Lugovskoj. Per. s pol'skogo yazyka: V.L. Vasyukov, E.N. SHul'ga. M.: "Kanon+" ROOI "Reabilitatsiya", 2009. 426 s.

27. Sibir'. Atlas Aziatskoj Rossii. Novosibirsk-Moskva: Feoriya, 2007. 664 s. 2021).

28. Global Biodiversity URL: https://www.cbd.int/gbo5 (data obrashheniya 17.07.

Бочарников В. Н., Егидарев Е. Г. Геоинформационное картографирование ареалов жизнедеятельности коренных малочисленных народов в природных ландшафтах Дальневосточного федерального округа.

В статье изложены результаты геоинформационного картографирования жизнедеятельности коренных малочисленных народов в ландшафотах территориальноадминистративных субъектов Дальневосточного федерального округа (ДФО) Российской Федерации. Обсуждается значимость государственного поддержания традиционного природопользования коренных малочисленных народов (КМНC) как компонента экологической политики по сохранению биоразнообразия и неистощительного использования биологических ресурсов. Представлены сведения о степени сохранности крупных природных геосистем физико-географических областей и крупных ландшафтных групп в пределах российского Дальнего Востока. Предлагается рассматривать крупные целостные территории дикой природы в качестве гарантированных государством возможностей сохранения биологического разнообразия, биосферных функций ландшафтов и природных ресурсов.

Ключевые слова: этнические ареаль, технологии ГИС, геоинфбормаиионное картографбирование, дикая природа, ДФО, ландшафбты

Bocharnikov V. N., Egidarev E. G. Geoinformation mapping of indigenous peoples in the natural landscapes of the Far Eastern Federal District.

The article presents the results of calculations and geoinformation mapping of ethnic areas of indigenous small-numbered peoples in the territorial-administrative subjects of the Far Eastern Federal District (Far Eastern Federal District) of the Russian Federation. Data on the degree of preservation of large natural geosystems (wildlife) for physical and geographical areas and large landscape groups of the Russian Far East are presented. The importance of the state support of the traditional nature use of the CMNS in the conditions of biodiversity conservation and sustainable use of resources is discussed. It is proposed to consider large integral territories of wildlife as state-guaranteed opportunities for preserving the landscape diversity of the Russian Far East.

Key words: ethnic areas, GIS technologies, geoinformation mapping, wilderness, Far Eastern Federal District, landscapes

Для цитирования: Бочарников В. Н., Егидарев Е. Г. Геоинформационное картографирование ареалов жизнедеятельности коренных малочисленных народов в природных ландшафтах Дальневосточного федерального округа // Ойкумена. Регионоведческие исследования. 2021. № 3. C. 8-23. DOI: $10.24866 / 1998-6785 / 2021-3 / 8-23$

For citation: Bocharnikov V. N., Egidarev E. G. Geoinformation mapping of indigenous peoples in the natural landscapes of the Far Eastern Federal District // Ojkumena. Regional researches. 2021. № 3. P. 8-23. DOI: 10.24866/1998-6785/2021-3/8-23 